\title{
THE EFFECTS OF EARTHQUAKES ON TOURISM: EVIDENCE FROM TURKEY
}

\author{
Sonat Bayramª , Gülsel Çiftçi ${ }^{\text {b, }}$ \\ ${ }^{a}$ School of Applied Sciences, Trakya University, Edirne, Turkey. \\ ORCID: 0000-0001-9885-8707 / e-mail: sonatbayram@trakya.edu.tr \\ ${ }^{\mathrm{b}}$ School of Applied Sciences, Trakya University, Edirne, Turkey. \\ ORCID: 0000-0001-9885-8707 / e-mail: gulselciftci@trakya.edu.tr
}

\begin{tabular}{|c|c|}
\hline KEYWORDS & ABSTRACT \\
\hline $\begin{array}{l}\text { Tourism } \\
\text { Environmental crisis } \\
\text { Earthquake } \\
\text { Turkey } \\
\text { CUSUM }\end{array}$ & $\begin{array}{l}\text { Turkey has been hit by many earthquakes during the last century. A } 7.4 \text { earthquake that lasted for } 45 \text { seconds } \\
\text { struck the Marmara Region on } 17 \text { August } 1999 \text { at 3:02 am. In addition to its destructive effects such as } \\
\text { property losses and personal injuries, it also had negative effects on the tourism industry. The cancellation of } \\
\text { package tours for foreign tourists in Turkey had a negative impact on travel agencies, hotels and airlines. The } \\
\text { purpose of the present study is to outline the economic impact of the } 1999 \text { Earthquake on tourist flows. For } \\
\text { this purpose, an event study was performed to evaluate the amount of loss between August } 1998 \text { and August } \\
2001 \text { due to the drop in the tourism industry. Additionally, the CUSUM and CUSUMSQ test, multiple linear } \\
\text { regression (MLR) model and prediction models were employed to identify the patterns of structural change. } \\
\text { The results show that the number of tourists decreased by about } 20 \% \text { following the earthquake. The results } \\
\text { of the CUSUM and CUSUMSQ estimation analysis based on the control variables suggest that if there had } \\
\text { been no earthquakes, the number of future tourists would have been approximately } 8 \% \text { higher than the actual } \\
\text { number of tourists who visited Turkey at that time. }\end{array}$ \\
\hline
\end{tabular}

\section{Introduction}

About $66 \%$ of Turkey's territory is covered by a total of 326 active faults and it is a tectonically active land where $70 \%$ of the population is at high risk of earthquake damage, danger and destruction (Ewing, Kruse, \& Özdemir, 2004) An earthquake with a magnitude of 7.4 which lasted for 45 seconds took place on 17 August 1999 at 3:02 am. 17,480 death were reported, 43,953 people were injured and 73,342 buildings were damaged. The earthquake affected a total of sixteen million people in ten cities, which were İstanbul, Kocaeli, Gölcük, Yalova, Sakarya, Tekirdağ, Bursa, Bolu, Eskișehir and Balıkesir (Petal \& Turkmen, 2002). İstanbul was one of the cities that received the greatest damage from the disaster. The fact that Istanbul is the biggest, the most popular and the most important touristic destination in Turkey brought about a crisis in every aspect, including the tourism industry in Turkey, which tarnished the safe image of the country creating a negative impact on purchasing decisions of the tourists. With the decreasing demand and cancellations of package tours, many tourism companies, such as travel agencies, hotels and airlines, have faced several difficulties. (Aktürk \& Albeni, 2002).

The purpose of the present research is to evaluate the economic effects of the 1999 Earthquake in Turkey on international tourist arrivals with a pioneering approach to understand the effects of a natural disaster on tourist mobility. To suit the purpose of the study, an event study was performed based on international tourist arrival statistics. Besides, the standard division of tourism parameters was employed and CUSUM tests were used to identify the pattern of structural change. The present paper applies the event study methodology, unlike the other prominent studies. There is an extensive body of literature on natural disasters, specifically earthquakes within the context of tourism. For example, $\mathrm{Wu}$ and Hayashi (2014) explored the impact of crises on Japan's foreign tourist arrival by applying Auto-Regressive Integrated Moving Average (ARIMA) interference designs that put the spotlight on assessing patterns of change and duration of effects by observing variations in parameters. Mendoza et al. (2012) Explored the role of natural disasters on inbound tourism in Chile using Seasonal Autoregressive Integrated Moving Average (SARIMA) designs of inbound tourism during the eruption. A recent study conducted by Cro and Martins (2017) compared the date of tourism crises and disasters to the dating of the structural breaks employing Bai and Perron's (2003) Structural break test method for the inappropriate structural breaks in tourist arrivals.

${ }^{*}$ Corresponding Author.

Received 03.01.2021; Received in revised form 22.02.2021; Accepted 23.02.2021 This article is licensed under a Creative Commons Attribution 4.0 International License. e-ISSN: 2687 - 3737 / @ 2021 The Authors. Published by Anadolu University. http://dx.doi.org/10.48119/toleho.851669 
This study focuses on the different studies in that it aims to fill the gap in the existing literature on the ex-post identification of tourism disaster events. This approach, therefore, contributes to the literature on emergencies or disasters in the tourism sector by exploring the effects of the negative shocks to the global market as a result of crises or natural disasters on the tourism industry closing the gap between the tourism industries. Eventually, the study continues by highlighting the findings, defining the limitations and offering directions for future research.

\section{Literature Review}

\subsection{Earthquake and Tourism Sector in Turkey}

Crises are paradoxical moments and possibilities from which different alternatives can emerge (Bramwell \& Lane, 2011). A crisis is defined by Faulkner (2001) as an action or non-action that interferes with or has a negative personal impact on the continuous functioning of the corporation, reasonable achievement of the company's goals or its viability. Crises could perhaps quickly spread again from the place of origin to distanced areas of the world and communicate in unusual ways based on environmental input, financial market linkages, the role of dynamic and human beings (Biggs, Hall, \& Stoeckl, 2012). Earthquakes are among the most significant and unpredictable types of environmental crisis (Vere-Jones, 1995). As reported by Ritchie (2008), whatever the origin of these natural disasters, there may be major economic and social impacts on both the destination and the world economy as a consequence of a decline in international tourist arrivals. Tourism damage caused by a crisis or a disaster also may have significant effects on economic systems (Sausmarez, 2007). Actions must therefore be taken as quickly and efficiently as possible across the crisis period to minimize adverse results and damage caused (Çiftçi, Küçükaltan, \&Menteş, 2017).
Considering its strategic position, Turkey is at high risk of being exposed to various types of crises (Kaya, Yetgin Akgün,\& Çiftci, 2020). Turkey is one of the destinations that have been seriously affected by earthquakes as it has been hit by a few series of earthquakes in the last decade, which had both geographical and financial outcomes. The crises in Turkey tarnished the safe image of the country and had a negative impact on the purchasing decisions of the tourists. Together with decreasing demand, many businesses and their employees faced difficulties in the tourism industry. The cancellation of package tours for foreign tourists in Turkey had a negative impact on travel agencies (Yetgin, Yllmaz, \& Çiftci, 2018). Tourism is the very heart of Turkey's economy, which is mainly based on tourism, automobile manufacturing, petrochemistry, and railway vehicle manufacturing and repair, basic metals, manufacturing of synthetic fibre and yarn, production of lacquer and paint. Yalova, Kocaeli, Bolu, Sakarya four of the most affected cities, had over 7\% of GDP and 14\% of industrial production compared to other industrial cities in Turkey with a national average per capita income nearly twice the amount of other industrial cities.

A60-kilometre highway route between Ankara and Istanbul, Gebze-Izmit-Arifiye railway, Adapazari's railway factory and rolling stock, Derince Harbour, local streets and provincial roads were among transport infrastructure that was severely damaged. Traffic between Istanbul and Ankara on the road and motorway was quickly restored (Bibbee, Gönenç, Jacobs, Konvitz, \& Price, 2000). The earthquake has some impacts on international tourist arrivals in Turkey as well. According to the Association of Turkish Travel Agencies (2019) report, it suggests that soon after the earthquake, there was a falloff in international visitor arrivals to Turkey during the period between August and December compared

Table 1. The Number of Tourists by Month and Year (1995-2001)

\begin{tabular}{llllllll}
\hline Month/Year & $\mathbf{1 9 9 5}$ & $\mathbf{1 9 9 6}$ & $\mathbf{1 9 9 7}$ & $\mathbf{1 9 9 8}$ & $\mathbf{1 9 9 9}$ & $\mathbf{2 0 0 0}$ & $\mathbf{2 0 0 1}$ \\
\hline January & 274,680 & 283,616 & 300,872 & 346,183 & 359,046 & 333,915 & 359,320 \\
February & 302,407 & 324,910 & 314,306 & 371,526 & 371,727 & 354,487 & 404,653 \\
March & 368,195 & 537,452 & 555,204 & 476,756 & 409,483 & 435,158 & 547,365 \\
April & 535,462 & 556,109 & 639,819 & 642,332 & 426,558 & 721,128 & 884,805 \\
May & 732,394 & 874,942 & $1,020,894$ & 986,237 & 691,313 & 986,376 & $1,231,562$ \\
June & 810,419 & 902,015 & $1,045,987$ & $1,062,961$ & 784,642 & $1,079,148$ & $1,387,955$ \\
July & $1,008,709$ & $1,106,242$ & $1,206,226$ & $1,288,439$ & 931,895 & $1,525,718$ & $1,776,821$ \\
August & $1,070,234$ & $1,153,755$ & $1,404,876$ & $1,460,075$ & $1,079,249$ & $1,419,244$ & $1,601,331$ \\
September & $1,054,871$ & $1,117,429$ & $1,297,455$ & $1,209,256$ & 876,261 & $1,368,538$ & $1,440,365$ \\
October & 836,025 & 909,397 & 947,462 & $1,035,237$ & 800,513 & $1,178,481$ & $1,065,825$ \\
November & 393,023 & 452,325 & 538,368 & 502,638 & 435,790 & 602,396 & 520,962 \\
December & 340,467 & 395,893 & 417,535 & 371,057 & 320,808 & 423,564 & 398,005 \\
TOTAL & $7,726,886$ & $8,614,085$ & $9,689,004$ & $9,752,697$ & $7,487,285$ & $10,428,153$ & $11,618,969$ \\
\hline
\end{tabular}

Source: TURSAB, Accessed from https://www.tursab.org.tr/istatistikler/turist-sayisi-ve-turizm-geliri, Date of Access: 02.08.2020. 


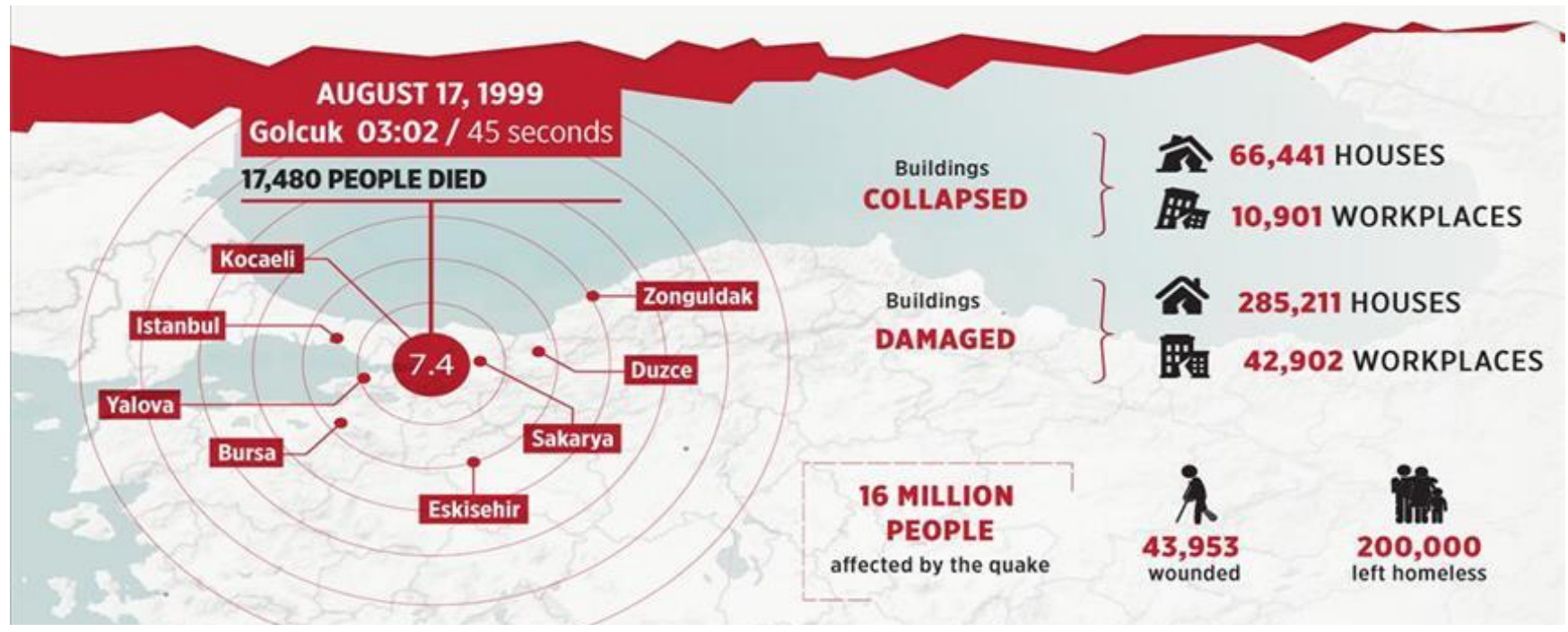

Figure 1. Map of the 1999 Golcuk Earthquake Zone

Source: Anadolu Agency (2018). Accessed from: https://www.aa.com.tr/en/life/turkey-observes-19th-anniversary-of-marmara-earthquake/1234211, Date of Access: 01.08.2020.

to the same period in 1998. Visitors arriving from abroad for the whole year $(7,487,285)$ decreased compared to the prior year $(9,752,697)$. The number of foreign tourists has a direct effect on tourism and the investment of government agencies. Thus decision-makers in either the tourism sector or governmental institutions need to have a reasonable overview of how crises impact the inbound tourist arrivals. With international tourism rapidly dropping in the months following the Earthquake of1999, the Turkish Government immediately concentrated on its North American target market, which had sent 2.5 million USD (Dickey \& Kohen, 1999; Goetzl \& Healy, 2000; Huang \& Min, 2002).

Tourism has been one of the sectors that suffered from the 1999 Earthquake with a 173 million USD loss. The revenue loss from the cancellations of congresses was 15 million USD, and the number of congress participants who had cancellations was 17,600 . 8,000 people left their vacation and returned to their countries. There was a 3 million

Table 2. Tourism Income by Years (1991- 2001)

\begin{tabular}{cc}
\hline Year & Income (million USD) \\
\hline 1991 & 2,654 \\
1992 & 3,639 \\
1993 & 3,959 \\
1994 & 4,321 \\
1995 & 4,957 \\
1996 & $5,962.1$ \\
1997 & $8,088.5$ \\
1998 & $7,808.9$ \\
1999 & 5,203 \\
2000 & 7,636 \\
2001 & $10,450.7$ \\
\hline
\end{tabular}

Source: TURSAB, Accessed from: https://www.tursab.org.tr/istatistikler/turist-sayisi-ve-turizm-geliri, Date of Access: 02.08.2020.
USD financial loss due to the tour cancellations. There were 156,000 reservation cancellations and a financial loss of 105,000 USD due to these cancellations in 1999 and the decline in the tourism sector was 27\% (TSPO, 2000; TÜRSAB, 2000).

Table 1 compares the number of tourist by month and year. Before the earthquake, There seems to be a considerable increase in the number of tourists. By September 1999, right after the earthquake, there was a sharp decrease in the number of tourists. Table 2 illustrates the tourism income by year. In 1999, there was a sharp decrease $(2,605$ million USD) in the tourism income. Liu et al. (2019) indicated that the tourism competitiveness of a country is shaped Studies emphasize the perceived risks of tourism industry service providers, and also the effect of crisis risk management on the competitive advantage of tourism. Mistilis and Sheldon (2006) stated that the tourism industry is fragmented and does not respond easily to disasters. This feature also highlights the need for industry-wide information systems that any business can use during a crisis. Because tourism is an important component of a country's economy responsive and broad-targeted disaster management plans should be prepared beforehand.

\subsection{Earthquake and Tourism Sector in Turkey}

Crises are devastating events that primarily have an impact on the surrounding environment and which may spread all over the world if they are failed to be stopped. Any type of crisis can lead to enormous impacts (Çiftçi, Çakır, \& Çakır, 2016). To illustrate the general scale of the devastation, the number of houses destroyed and during the 1999 earthquake would be at least four times the number of houses destroyed. 1995 Kobe Earthquake and 12 times the number of damaged buildings in the 1994 Northridge Earthquake (OECD, 2004). Eight cities that were severely affected by the earthquake account for $34.7 \%$ of the total GNP and generate 
over $46.7 \%$ of the national industrial product. The cities of Sakarya, Kocaeli and Yalova held about 6.3\% of GNP and $13.1 \%$ of the industrial production.

Figure 1 illustrates the earthquake zone. The 1999 Earthquake in Izmit is among the worst earthquakes which have cost far too many lives. Nevertheless, the impacts of the earthquake can indeed be measured solely by the amount of losses, as well as by their effect on rescuers and their life quality regarding the crisis, all of whom have an impact on sustainability. Because sustainable tourism can be defined as the sustainable growth of tourist arrivals and the development of tourism infrastructure (Kontogeorgopoulos, 1999).

\section{Methodology}

\subsection{Data and Variable Selection}

The research data are annually reported and limited to the period between 1985 and 2005 to analyse the possible effects of the earthquake. Showing changes due to Turkey's geopolitical risks from the year 2005 onwards on behalf of tourism data can be separated from the effects of the earthquake have been made to such a restriction. However, the data between 1985-2018 is used for the Maki Cointegration Test. The number of foreigners visiting Turkey is obtained from the Turkish Central Bank, Ministry of Development, Ministry of Culture and Tourism, Turkish Statistical Institute, Ministry of Finance, Ministry of Interior General Directorate of Security. GDP (in USD), the market capitalization of the listed domestic companies (in USD), GDP per capita growth (in USD), GNI (in USD) and Stocks traded, total value (in USD) data are employed as control variables.

Event Study and Principal Component Analysis are widely used in studies on finance and economy to measure the reaction experienced as a reaction to a particular event or as a result of a situation called an important event occurring (Xu, Chang, \& Hsu, 2020). This event was identified as a Malaysia Airlines Flight 370 ("MH370") disaster in the study conducted by Zhao et al (2020), and the EventOriented Text Retrieval method was tried using Deep Neural Network. Zhao et al. (2020) define the influential meanings of an event as follows:

Definition 1. An event is a specific thing that happens at some specific time and place.

Definition 2. An event is a specific occurrence involving participants. An event is something that happens. An event can frequently be described as a change of state.

Definition 3. An event is an explicit occurrence with or without participants. An event can correspond to multiple topics. An event contains multiple sub-events.

\subsection{Model Specification}

Event study has been widely used as a method in economics and finance. According to Campbell et al. (1997), an important feature of a successful event study is that it can determine the exact date (date of the earthquake 17.08.1999) of the event. In cases where it is difficult to identify the time and place of an event, conducting a case study might prove less useful. For example, it may be difficult for organizations to determine the effects of legal changes on wealth by employing a case study methodology.

The problem is that legal changes are discussed in the political arena over time, and the associated asset effects are gradually included in the value of a company as the probability of the adopted change increases. Research employing event study methodology has shown that prices respond to new information, as we generally expect in a rational market. The event study methodology is popularly seen in financial services (Binder, 1998; Strong, 1992). By many it that is the damage assessment for instances of legal responsibility in particular situations, such as that of the Tylenol toxicosis case of 1982 (Mitchell, 1989). Mazzocchi (1999) submitted a proposal for non-financial statistics on food price.

To apply the method of event analysis in the tourism sector, it is important to identify the event correctly and determine its constraints (other geopolitical events in the post-earthquake period) that will disclose the results of the current event, irrespective of other consequences. Therefore, the relationship between the earthquake, which is identified as a significant event, and the structural changes observed in macroeconomic variables in the post-earthquake period, and the impact of the event (earthquake) is first analysed using the Maki Cointegration method, followed by the CUSUM test, multiple linear regression (MLR) model and prediction models. This approach will be a guide for calculating the impacts on systemic change of changes which are significant events in the tourism sector.

In the study conducted by Chow (1960), to test the equation between coefficient sets in two linear regressions, the sum of the squares assuming the equation and the sum of the squares without assuming the equation are obtained. The subsequent addition rate, which is adjusted according to the corresponding degrees of freedom, of the difference between these two sums is distributed as the $F$ ratio under the null hypothesis. This sum of second squares is obtained from the first instance of $n$ observations only when the second sample is not large enough to calculate a separate regression. It shows how the general linear hypothesis theory is applied to the problem and how the estimation range and covariance analysis are related to each other and the general linear hypothesis theory.

Page (1954) indicated that the Cumulative Sum (CUSUM) charts are used to detect small shifts in a process mean. Those named after Chow (1960) are most powerful when the break date is known, whereas those based on recursive residuals can help 
identify the pattern of structural change, although less powerfully. Brown et al. (1975) tested CUSUM and CUSUMSQ methods developed to investigate the stability of regression relationships over time. Recursive residues, defined to be uncorrelated with zero means and constant variance are introduced and tests based on CUSUM and CUSUM of squares recursive residues are developed. Advanced techniques based on moving regressions in which the regression model is fitted from a data segment moving through the series and regression models with polynomial coefficients over time are examined.

Alternative modelling to the Chow estimation test was developed by Fisher (1970) and a statistical test was conducted on the difference between the estimates where the estimates represent "unconditional values" and the actual values. The aim here is to test the significance of the difference between space and time of the difference between these "excess residuals". An "event window" is defined as a series of periods that may be potentially affected by the event.

The breakpoint test used in the analysis was developed by Perron (1989) and tests of the unit root hypothesis against the alternative hypothesis of trend stability were carried out by breaking the trend that occurred in the Great Crash of 1929 or the 1973 oil price shock. Perron's analysis includes Nelson-Plosser's macroeconomic data series as well as the three-month post-war real gross national product (GNP) series. Tests rejected the unit-root null hypothesis for most of the series. Perron (1989) assumed that the Great crash and oil price shock could be treated as external events. In a study by Perron and Vogelsang (1992), the statistics of interest are similar to those proposed by Perron, to test for the presence of such a change in a stationary time series for unit root, the minimum statistic decreases tested with the general possible breakpoints.

To demonstrate the relative scale of the disaster, the number of the damaged buildings in the 1999 Earthquake was at least 4 times the number of the damaged buildings in the 1995 Kobe Earthquake and 12 times the number of damaged buildings in the 1994 Northridge Earthquake (OECD, 2004). 8 cities that were severely affected by the earthquake account for $34.7 \%$ of the total GNP and generate over $46.7 \%$ of the national industrial product.

The effects of the earthquake can be divided into direct impacts and indirect effects on the tourism industry. One of the direct effects is the number of tourists, which decreased by $20 \%$ in 1999 compared to the previous year. The number of tourists visiting Turkey in 1998 was 9,431,280, which decreased to $7,487,365$ in 1999 . Tourism revenues decreased by $28 \%$ and the loss of direct income was 1.9 billion USD with a significant decrease in exports and tourism revenues (OECD, 2004).

The key indirect effects on the tourism sector holding $7.2 \%$ of GDP due to a decline in economic activity and a $1.6 \%$, net decline in GNP growth whereas GDP per capita dropped by $8.63 \%$. In the following year, the value of companies listed on the stock exchange dropped by $144 \%$. Tourism investments and sectoral growth were also adversely affected as a result of the decline in economic activity after the earthquake and it even prevented the sector from reaching its potential in the current year. Centre for Research on the Epidemiology of Disasters (CRED, 2015) stated that the estimated total cost for both losses of income and loss of national wealth varies between 9 and 13 billion USD and 6 to 10 billion USD, respectively. The World Bank (1999) estimated the loss at over 15 billion

Table 3. Descriptive Statistics of Variables

\begin{tabular}{lllllll}
\hline $\begin{array}{l}\text { Variable } \\
\text { Name }\end{array}$ & D1 & I1 & I2 & I3 & I4 & I5 \\
\cline { 2 - 7 } & $\begin{array}{l}\text { The Number } \\
\text { of Tourist Co- } \\
\text { ming to Turkey } \\
\text { (Annually) }\end{array}$ & $\begin{array}{l}\text { GDP Growth } \\
\text { \% (US\$) }\end{array}$ & $\begin{array}{l}\text { Market Capita- } \\
\text { lization of The } \\
\text { Listed Domestic } \\
\text { Companies } \\
\text { (Billion US\$) }\end{array}$ & $\begin{array}{l}\text { GDP Per Ca- } \\
\text { pita Growth \% } \\
\text { (US\$) }\end{array}$ & $\begin{array}{l}\text { GNI Growth \% } \\
\text { (US\$) }\end{array}$ & $\begin{array}{l}\text { Stocks Traded, } \\
\text { Total Value } \\
\text { (Billion US\$) }\end{array}$ \\
\hline Mean & 20.307 .184 & 4.681 .360 & 25.03108 & 3.123 .246 & 4.696 .672 & 35.514 .290 \\
Median & 20.472 .360 & 6.258 .083 & 23.598 .220 & 4.603 .105 & 6.198 .235 & 37.788 .980 \\
Maximum & 36.837 .900 & 11.113 .500 & 44.049 .530 & 9.423 .771 & 11.106 .920 & 60.798 .740 \\
Minimum & 6.525 .202 & -5.962 .311 & 12.200 .660 & -7.357 .004 & -6.957 .255 & 8.880 .015 \\
Std. Dev. & 10.498 .255 & 4.703 .416 & 8.937 .337 & 4.620 .743 & 4.969 .889 & 12.005 .900 \\
Skewness & 0.101 .038 & -1.067 .772 & 0.586 .756 & -1.061 .049 & -1.124 .728 & -0.172 .600 \\
Kurtosis & 1.517 .433 & 3.082 .994 & 2.443 .969 & 3.089 .169 & 3.218 .518 & 2.711 .358 \\
Jarque-Bera & 2.425 .410 & 4.948 .052 & 1.826 .825 & 4.887 .188 & 5.533 .449 & 0.219 .351 \\
Probability & 0.297 .392 & 0.084 .245 & 0.401 .153 & 0.0868 .480 & 0.062 .868 & 0.896 .125 \\
Sum & $5.28 \mathrm{E}+08$ & $121.715,4$ & $650.808,2$ & 81.204 .400 & 122.113 .500 & 923.371 .600 \\
Sum Sq. Dev. & $2.76 \mathrm{E}+15$ & $553.053,1$ & 1.996 .900 & 533.781 .700 & 617.495 .000 & 3.603 .542 \\
Observations & 26 & 26 & 26 & 26 & 26 & 26 \\
\hline
\end{tabular}


USD. When the indirect and long-term impacts are carefully calculated, the total cost of a 9-10\% drop in GDP in 2000 is estimated at 20 billion USD. The share of the earthquake zone in total imports was $15 \%$ and its share in total exports was 5\%. Exports and imports decreased by $6 \%$ and $11 \%$, respectively. Despite a $27 \%$ drop in the foreign trade deficit, its final impact on the economy is difficult to interpret.

Bibbee et al. (2000) indicated that in addition to temporary interruptions in labour supply due to deaths, injuries and motivation, SMEs and large enterprises in the region were also concerned about the possible migration of qualified workers. As a result, the majority of large enterprises participated in care and housing for their employees, who seemed to convince many of them to stay in the region.

Data on Turkish tourism are annually reported and limited to the period between 1985 and 2005 to analyse the possible effects of the earthquake. Although the tourism industry in Turkey has been experiencing some geopolitical risks, such as conflicts, political instability, security issues, and terror (Demir, Simonyan, Chen, \& Marco Lau, 2020), the negative impact of the earthquake is obvious from the year 2005 onwards. Descriptive statistics for the variables are shown in Table 3. Next, Multiple Linear Regression and Correlation analyses were performed to reveal the level of relationship between variables. The data was obtained from The World Bank Database.

\section{Findings}

In the case of a structural break in the applied time series analysis, incorrect results may occur in traditional cointegration tests. Gregory and Hansen (1996) developed a cointegration test that allowed a single structural break followed by Hatemi-J (2008) who developed cointegration tests that allowed two structural breaks. These methods assume one or two structural breaks. In the case of more than two structural breaks in the series, the cointegration test developed by Maki (2012), which provides up to five structural breaks, might be used. The fact that it allows more structural breaks in the series makes the Maki cointegration test preferable. Maki (2012) introduced the cointegration test into the literature using the following four models:

$$
\begin{aligned}
& y_{\mathrm{t}}=\mu+\sum_{\mathrm{i}=1}^{\mathrm{k}} \quad \mu_{i} D_{i, t}+\beta^{\prime} x_{t}+u_{t}
\end{aligned}
$$

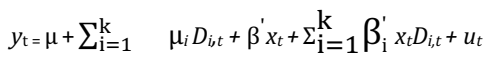

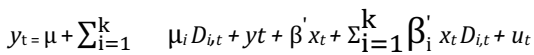

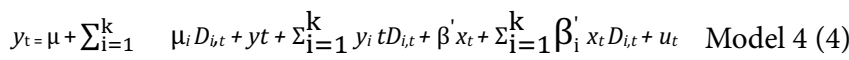

The four models (Model 1, Model 2, Model 3, and Model 4) demonstrate with the break in intercept and without trend; with break in intercept and coefficients and without trend; with break in intercept and coefficients and with the trend; and with the break in intercept, coefficients and trend, respectively. The maximum number of fractions in the equations is indicated by $\mathrm{k}$. When $\mathrm{k}=1$, the models are similar to Gregory ve Hansen (1996) and when $\mathrm{k}=2$, the models are similar to Hatemi-J (2008). In the equations, the $\mathrm{H}: 0$ hypothesis states that there is no cointegration relationship under the structural break, while the $\mathrm{H}: 1$ hypothesis states that there is a cointegration relationship under the structural break (Maki, 2012).

Table 4 indicates that all variables have a unit root at the level for the ADF unit root test. Moreover, at first differences the variables are stationary. Therefore, the null hypothesis which states that series have unit root is rejected. In this case, the long-term relationship between the variables can be investigated. In this context, the long-term relationship between variables is examined with the Maki Cointegration Test. The Maki Cointegration Test, which was developed by Maki (2012), is based on structural breaks developed by Kapetanios (2003) tests. When multiple numbers of breaks exist, Maki Cointegration Test allows structural breaks in a cointegration relationship, which is the main advantage of the test.

Dickey and Fuller (1979) demonstrate that this statistic does not obey the traditional Student t-distribution under the null hypothesis of a unit root, and they derive asymptotic results and simulate critical values for different test and sample sizes. More recently, a much larger range of simulations was introduced by MacKinnon $(1991,1996)$ than those tabulated by Dickey and Fuller. In addition, for the simulation performance, MacKinnon estimates response surfaces, allowing Dickey-Fuller critical values and values for arbitrary sample sizes to be measured. The variables (D1, I1, I2, I3, I4, I5)

Table 4. Unit Root Test

\begin{tabular}{llllll}
\hline \multicolumn{2}{l}{ Augmented Dickey-Fuller (ADF) Test } \\
\hline & Symbol & \multicolumn{3}{l}{ Level } & \multicolumn{3}{l}{ First Difference } \\
\hline & & T-Statistics & Prob & T-Statistics & Prob \\
Tourist number & D1 & -1.465623 & 0.5353 & $-6.492480^{*}$ & 0.0000 \\
GDP Growth & I1 & -1.094997 & 0.7028 & $-5.419606^{*}$ & 0.0002 \\
GDP per capita & I3 & -1.155965 & 0.6781 & $-5.393453^{*}$ & 0.0002 \\
GNI Growth & I4 & -1.100027 & 0.7008 & $-5.437577^{*}$ & 0.0001 \\
Stocks traded & I5 & -2.197124 & 0.2118 & $-6.416285^{*}$ & 0.0000 \\
\hline
\end{tabular}

${ }^{*}$ denotes that the series are stable at $1 \%$ significance level. Fixed term model is used. 
included in the analysis (significance level $\% 1, \% 5$, $\% 10$ ) do not have a unit root problem.

Null Hypothesis: D1, I1, I2, I3, I4, I5 contains a unit root:

$$
\begin{aligned}
& y_{t}=c+\delta t+\phi y_{t-1}+\beta_{1} \Delta y_{t-1}+\ldots+\beta_{p} \Delta y_{t-p}+\varepsilon_{t} \\
& H_{0}: \phi=1 \\
& H_{a}: \phi<1
\end{aligned}
$$

The complexity of regulating their size while the mechanism is stationary but extremely self-regressive is an important argument against the use of tests for the null hypothesis of stationarity. In this case, the socalled KPSS test proposed by Kwiatkowski, Phillips, Schmidt And Shin (1992) is probably the best-known test for stationarity in econometrics: it too frequently rejects the true hypothesis of stationarity, again leading to an undue preference for the hypothesis of unit root non-stationarity. The variables (D1, I1, I2, I3, I4, I5) included in the analysis (significance level $\% 1, \% 5, \% 10$ ) have a trend stationarity problem. The trend influence, however, stems from the seasonal characteristics of the data and is not an obstacle to study.

Null Hypothesis: D1, I1, I2, I3, I4, I5 is trend stationery:

$$
\begin{aligned}
& y_{t}=c_{t}+\delta t+u_{1 t} \\
& c_{t}=c_{t-1}+u_{2 t} \\
& u_{2 t} \sim i . i . d\left(0, \sigma^{2}\right) \\
& H_{0}: \sigma^{2}=0 \\
& H_{a}: \sigma^{2}>0
\end{aligned}
$$

Table 5. Stationarity Test Results
The key difference between the two tests is that the non-parametric test is KPSS and the parametric test is Leybourne-McCabe. The Leybourne-McCabe stationary test is similar in spirit to one recently suggested by KPSS, but under the respective null (and alternative) hypotheses, the two experiments vary fundamentally in their approaches to the handling of autocorrelation, based on an explicit parametric model. Similar to the KPSS test results, according to Leybourne-McCabe test results, the variables (D1, I1, I2, I3, I4, I5) are included in the analysis (significance level \%1, 5\%, 10\%) have a trend stationarity problem. The trend influence, however, stems from the seasonal characteristics of the data and is not an obstacle to study.

Null Hypothesis: D1, I1, I2, I3, I4, I5 is a trend stationary AR(p) Process:

$$
\begin{aligned}
y_{t} & =c_{t}+\delta t+b_{1} y_{t-1}+\ldots+b_{p} y_{t-p}+u_{1 t} \\
c_{t} & =c_{t-1}+u_{2 t} \\
u_{1 t} & \approx i . i . d\left(0, \sigma_{1}^{2}\right) \\
u_{2 t} & \approx i . i . d\left(0, \sigma_{2}^{2}\right) \\
H_{0} & : \sigma^{2}=0 \\
H_{a} & : \sigma^{2}>0
\end{aligned}
$$

\begin{tabular}{|c|c|c|c|c|c|c|c|c|c|c|c|c|c|c|}
\hline \multirow{6}{*}{ D1 } & \multirow{6}{*}{$\begin{array}{l}\text { Variables } \\
\\
\text { The Number of Tourist } \\
\text { Coming to Turkey } \\
\text { (Annually) DiffDiff }\end{array}$} & \multicolumn{4}{|c|}{ Augmented Dickey-Fuller Test } & \multicolumn{3}{|c|}{ KPSS Test } & \multicolumn{3}{|c|}{ Leybourne-McCabe Test } & \multicolumn{3}{|c|}{ Phillips-Perron Test } \\
\hline & & Significance Level & 0.01 & 0.05 & 0.1 & 0.01 & 0.05 & 0.1 & 0.01 & 0.05 & 0.1 & 0.01 & 0.05 & 0.1 \\
\hline & & Null Rejected & true & true & true & false & false & false & false & false & false & true & true & true \\
\hline & & P-Value & 0.001 & 0.001 & 0.001 & 0.1 & 0.1 & 0.1 & 0.1 & 0.1 & 0.1 & 0.001 & 0.001 & 0.001 \\
\hline & & Test Statistic & -98.304 & -98.304 & -98.304 & 0.015158 & 0.015158 & 0.015158 & 0.0056721 & 0.0056721 & 0.0056721 & -98.304 & -98.304 & -98.304 \\
\hline & & Critical Value & -26.635 & -19.507 & -16.039 & 0.216 & 0.146 & 0.119 & 0.216 & 0.146 & 0.119 & -26.635 & -19.507 & -16.039 \\
\hline \multirow{4}{*}{ I1 } & \multirow{4}{*}{$\begin{array}{l}\text { GDP Growth \% (current } \\
\text { US\$) DiffDiff }\end{array}$} & Null Rejected & true & true & true & false & false & false & false & false & false & true & true & true \\
\hline & & P-Value & 0.001 & 0.001 & 0.001 & 0.1 & 0.1 & 0.1 & 0.1 & 0.1 & 0.1 & 0.001 & 0.001 & 0.001 \\
\hline & & \begin{tabular}{|l|} 
Test Statistic \\
\end{tabular} & -121.907 & \begin{tabular}{|l|}
-121.907 \\
\end{tabular} & -121.907 & 0.020052 & 0.020052 & 0.020052 & 0.016198 & 0.016198 & 0.016198 & -121.907 & \begin{tabular}{|l|}
-121.907 \\
\end{tabular} & -121.907 \\
\hline & & \begin{tabular}{|l} 
Critical Value \\
\end{tabular} & -26.635 & -19.507 & -16.039 & 0.216 & 0.146 & 0.119 & 0.216 & 0.146 & 0.119 & -26.635 & -19.507 & -16.039 \\
\hline \multirow{4}{*}{ I2 } & \multirow{4}{*}{$\begin{array}{l}\text { Market Capitalization of } \\
\text { The Listed Domestic } \\
\text { Companies (Billion, } \\
\text { Current US\$) DiffDiff }\end{array}$} & Null Rejected & true & true & true & false & false & false & false & false & false & true & true & true \\
\hline & & \begin{tabular}{|l|} 
P-Value \\
\end{tabular} & 0.001 & 0.001 & 0.001 & 0.1 & 0.1 & 0.1 & 0.1 & 0.1 & 0.1 & 0.001 & 0.001 & 0.001 \\
\hline & & Test Statistic & -108.665 & -108.665 & -108.665 & 0.016014 & 0.016014 & 0.016014 & 0.014805 & 0.014805 & 0.014805 & -108.665 & -108.665 & -108.665 \\
\hline & & Critical Value & -26.588 & -19.502 & -16.046 & 0.216 & \begin{tabular}{|l|}
0.146 \\
\end{tabular} & 0.119 & 0.216 & 0.146 & 0.119 & -26.588 & -19.502 & -16.046 \\
\hline \multirow{4}{*}{ I3 } & \multirow{4}{*}{$\begin{array}{c}\text { GDP Per Capita Growth } \\
\% \text { (Current US\$) } \\
\text { DiffDiff }\end{array}$} & Null Rejected & true & true & true & false & false & false & false & false & false & true & true & true \\
\hline & & \begin{tabular}{|l|} 
P-Value \\
\end{tabular} & 0.001 & 0.001 & 0.001 & 0.1 & 0.1 & 0.1 & 0.1 & 0.1 & 0.1 & 0.001 & 0.001 & 0.001 \\
\hline & & \begin{tabular}{|l|} 
Test Statistic \\
\end{tabular} & -122.035 & -122.035 & -122.035 & 0.020037 & 0.020037 & 0.020037 & 0.016184 & 0.016184 & 0.016184 & -122.035 & -122.035 & -122.035 \\
\hline & & Critical Value & -26.635 & -19.507 & -16.039 & 0.216 & 0.146 & 0.119 & 0.216 & 0.146 & 0.119 & -26.635 & -19.507 & -16.039 \\
\hline \multirow{4}{*}{ I4 } & \multirow{4}{*}{$\begin{array}{c}\text { GNI Growth \% (Current } \\
\text { US\$) DiffDiff }\end{array}$} & Null Rejected & true & true & true & false & false & false & false & false & false & true & true & true \\
\hline & & \begin{tabular}{|l|} 
P-Value \\
\end{tabular} & 0.001 & 0.001 & 0.001 & 0.1 & 0.1 & 0.1 & 0.1 & 0.1 & 0.1 & 0.001 & 0.001 & 0.001 \\
\hline & & Test Statistic & -126.173 & \begin{tabular}{|l|}
-126.173 \\
\end{tabular} & -126.173 & 0.020049 & 0.020049 & 0.020049 & 0.016184 & 0.016184 & 0.016184 & -126.173 & -126.173 & -126.173 \\
\hline & & Critical Value & -26.635 & -19.507 & -16.039 & 0.216 & 0.146 & 0.119 & 0.216 & 0.146 & 0.119 & -26.635 & -19.507 & -16.039 \\
\hline \multirow{4}{*}{ I5 } & \multirow{4}{*}{$\begin{array}{l}\text { Stocks Traded, Total } \\
\text { Value (Billion, Current } \\
\text { US\$) DiffDiff }\end{array}$} & Null Rejected & true & true & true & false & false & false & false & false & false & true & true & true \\
\hline & & \begin{tabular}{|l} 
P-Value \\
\end{tabular} & 0.001 & 0.001 & 0.001 & 0.1 & 0.1 & 0.1 & 0.1 & 0.1 & 0.1 & 0.001 & 0.001 & 0.001 \\
\hline & & Test Statistic & -90.767 & -90.767 & -90.767 & 0.015162 & 0.015162 & 0.015162 & 0.014065 & 0.014065 & 0.014065 & -90.767 & -90.767 & -90.767 \\
\hline & & Critical Value & -26.635 & -19.507 & -16.039 & 0.216 & 0.146 & 0.119 & 0.216 & 0.146 & 0.119 & -26.635 & -19.507 & -16.039 \\
\hline
\end{tabular}

In checking for a unit root, Phillips and Perron (1988) suggest an alternative (nonparametric) method of controlling for serial correlation. The PP method calculates the non-augmented test DF equation and modifies the coefficient ratio such that the asymptotic distribution of the test statistics is not influenced by the serial correlation. The PhillipsPerron test does a nonparametric correction to the 
Table 6. Maki Cointegration Test Results

\begin{tabular}{|c|c|c|c|c|c|}
\hline & Test Statistics & \%1 Critical Value & $\% 5$ Critical Value & $\% 10$ Critical Value & Break Dates \\
\hline Model 1 & -7.652 & -7.053 & -6.494 & -6.220 & $1994,1996,2010,2012,2014$ \\
\hline
\end{tabular}

t-test statistics by adding lags of $\Delta y t$ as regressors in the test equation. The Augmented Dickey-Fuller test solves this problem. The test is robust in relation to unspecified autocorrelation and heteroscedasticity in the test equation disturbance phase. The variables (D1, I1, I2, I3, I4, I5) included in the analysis (significance level \%1, \%5, \%10) do not have a unit root problem.

Null Hypothesis: D1, I1, I2, I3, I4, I5 contains a unit root:

$$
\begin{aligned}
& y_{t}=c+\hat{I}^{\prime} t+\alpha y_{t-1}+\varepsilon_{t} \\
& H_{0}: \alpha=1 \\
& H_{a}: \alpha<1
\end{aligned}
$$

The results in Table 6 show that the null hypothesis is rejected at all levels of significance for Model 1. In this case, there is a long-term relationship between the variables according to the Maki cointegration test results. Furthermore, the results indicate that there are five structural breaks dates, which are 1994, 1996, 2010, 2012 and 2014. In 1994, Turkey experienced a currency crisis which resulted in a $6 \%$ drop in production, inflation rose to three-digit rates, the Central Bank lost half of its reserves, and the exchange rate (against the US USD) decreased by more than half in the first three months of the year. In 1998, the global economic crisis had a negative impact on tourism in Turkey. In 1999, the earthquake had huge consequences for the tourism industry in Turkey whereas economic crises in 2012 and 2014 had some adverse effects on tourism.

According to CUSUM test results, recursive residuals of the tourist number variable changed after the earthquake and it can help identify the pattern of structural change when the break date is known (Page, 1954; Chow 1960). Figure 1 demonstrates that the number of tourists is affected

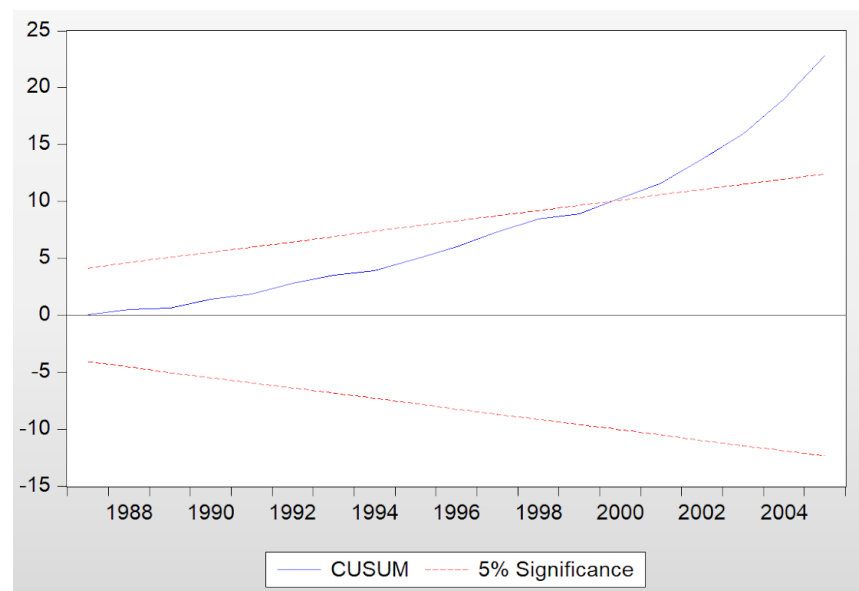

Figure 2. CUSUM Test Results by the earthquake, which is also seen one year later in 2000 (Figure 2). The CUSUM test was developed to calculate the breakdown of tourist numbers with the 1999 Earthquake and the resulting economic slowdown, with recursive residuals. The aim here is to address the deviation in the number of tourists with a structural break, irrespective of other world political, social, and economic events. The variables used in the model produced are therefore limited to the number of visitors, GDP, GDP per capita, GNI, Stocks exchanged.

When we look at the number of tourist arrivals in Figure 3, we see a dramatic decrease, approximately $20 \%$, immediately after the earthquake. Some of the fluctuations in the number of tourists in the postearthquake period, in particular, the fluctuations observed as a result of the risks called geopolitical risks (like 2016) are excluded from the scope of the study and the date of the event is taken as the date of the earthquake, 17.08.1999 (Figure 3).

GNP Growth seems to be affected by the earthquake, and it decreased from $-0.8 \%$ to $-1,6 \%$ (Figure 4). GNP dropped by $7.6 \%$ and $4.9 \%$ yearon-year in the third and fourth quarter of 1999 , respectively. In the affected area, 140,000 people remained unemployed. The earthquake's fiscal impact was US $\$ 1,8$ billion in 1999, USD 4.2 billion in 2000 ( $1.0 \%$ and $1.9 \%$ respectively of GNP) (OECD, 2004).

The estimation test was developed by Chow (1960) and Fisher (1970) used alternative modelling to estimate "unconditional values" and confront the actual values. The aim here is to test the significance of the difference between space and time of the difference between these "excess residuals". An "event window" is defined as a series of time periods that may be potentially affected by the event. The estimation results (Figure 5) shows the loss of tourists due to the earthquake by comparing the expected number of tourists if there had been no earthquakes (the estimation was

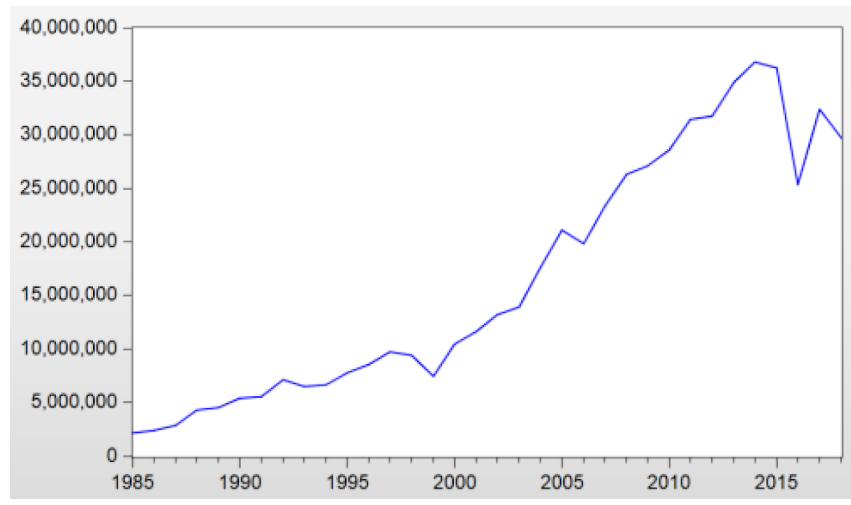

Figure 3. Number of Tourist Arrivals (1985-2018) 


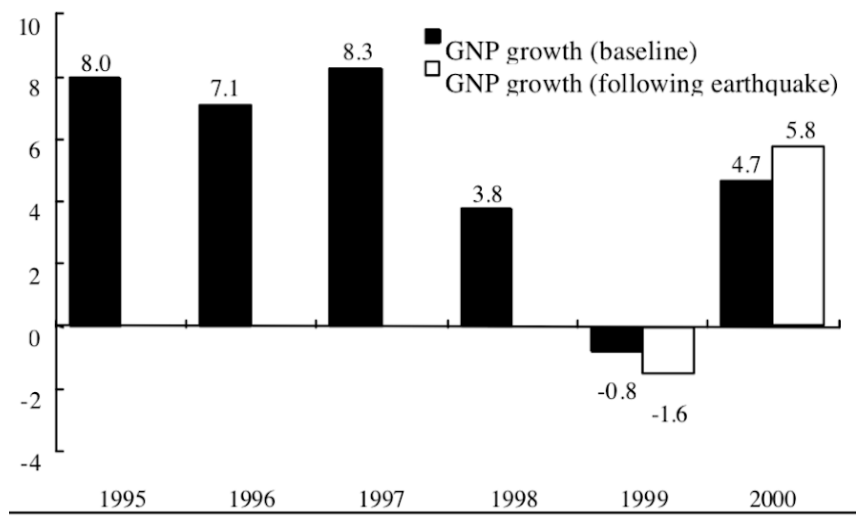

Figure 4. GNP Growth (\%)

Source: The World Bank, Turkey Country Office, Marmara Earthquake Assessment, 14 September 1999, Working Paper 27380, 15.

produced using control variables such as GDP (USD), the market capitalization of the listed domestic companies (USD), GDP per capita growth (USD), GNI (USD) and Stocks traded, total value (USD) and the actual number of tourists coming to the country). The results of the estimation analysis based on the control variables show that the estimated number of expected tourists would be approximately 8\% higher than the number of incoming tourists if there had been no earthquakes.

The analysis of the relationship between the approximate values of the number of tourists in the aftermath of the earthquake (there is already a Maki Cointegration relationship between them) shows that the macroeconomic issues encountered after the earthquake have seriously affected the tourism sector's efficiency. The decrease in productivity experienced due to the inability to make sectoral investments, in particular, due to the post-earthquake economic crisis, was also reflected in the number of incoming tourists with an average 8 percent gap between the actual and expected number of tourists (Figure 5 and Figure 8).

The Regression Model was created with Time Series Errors to evaluate the effect of the deviations (I1-I5) in the independent variables included in the study. The number of visitors (D1) included in the equation as the dependent variable and with the effect of the 1999 Earthquake on the independent variables, which is considered to be a significant event. Regression models with time series errors attempt to explain the mean behaviour of a response $(y t, t=1, \ldots, T)$ by using multiple linear regression

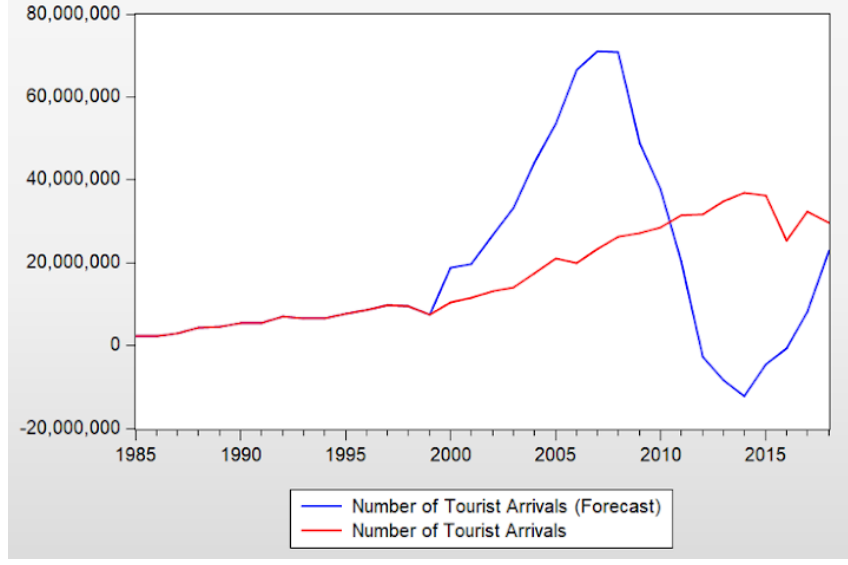

Figure 5. Forecast Analysis Results

(MLR) to compensate for linear predictor effects (Xt). The errors (ut), however, called unconditional disturbances, are time series rather than white noise, which is a divergence from the linear model assumptions. Regression models with time series errors maintain the sensitivity definition of regression coefficients $(\beta)$ unlike the ARIMA model that contains exogenous predictors (Hyndman, 2010). Multiple linear regression model of time series D1Diff is calculated using the following equation:

$$
X_{1} \beta_{1}+\ldots+X_{5} \beta_{5}+\varepsilon_{t}
$$

The results reveal that there is no regression relationship between the dependent variable (D1 number of tourist) and independent variables (I1I5) (Table 7 and Table 8).

The relationship between the first difference D1Diff series and the generated MLR regression time series is optimized with the ensemble regression model (Figure 6-7) and the true value, predicted, and error values are seen in the optimization model provided between the D1 variable and the GDP growth (I1) variable (Figure 8). With the estimation model, it is shown that after the 1999 Earthquake, the number of tourists remained below the required amount, depending on the GDP Growth (I1) variable (Figure 8). The sector seems to be unable to reach its real potential, and tourism demand remained below the planned level due to the post-earthquake economic slowdown and the decline in GDP growth that negatively affected tourism investments, which suggests that the tourism industry performed on average $8 \%$ below its projected capacity.

The number of tourist arrivals and independent variables [GDP (USD) (I1), GDP per capita growth

Table 7. Multiple Linear Regression Model (MLR_D1Diff) Estimation Results

\begin{tabular}{lllll}
\hline Parameter & Value & Standard Error & t Statistic & P-Value \\
\hline Intercept & $933,612.1003$ & $655,093.1604$ & 1.4252 & 0.17033 \\
Beta $\{$ I1Diff $\}$ & $8,617,886.3157$ & $1,0819,728.8614$ & 0.7965 & 0.43558 \\
Beta\{I2Diff $\}$ & $-16,970.8266$ & $53,519.8099$ & -0.31709 & 0.75463 \\
Beta $\{$ I3Diff $\}$ & $-6,297,005.3517$ & $11,065,650.5361$ & -0.56906 & 0.57598 \\
Beta\{I4Diff $\}$ & $-2,174,201.7903$ & $1,505,758.3157$ & -1.4439 & 0.16505 \\
Beta $\{$ I5Diff $\}$ & $28,929.558$ & $64,168.2792$ & 0.45084 & 0.65721 \\
\hline
\end{tabular}


Table 8. Goodness of Fit Results

\begin{tabular}{ll}
\hline AIC & 825.3877 \\
BIC & 832.701 \\
\hline
\end{tabular}

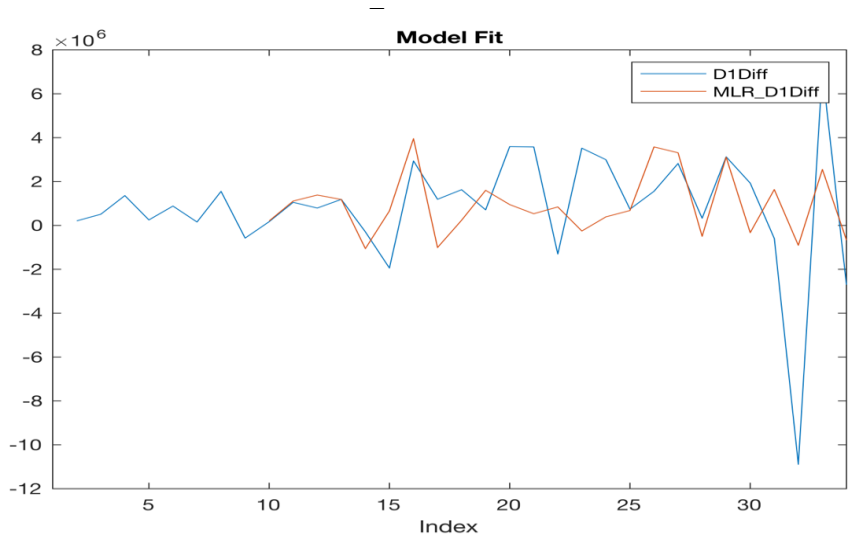

Figure 6. Plot the fit of model MLR_D1Diff time series D1Diff

(USD) (I3), GNI (USD) (I4) and exchanged stocks, overall value (USD) (I5)] are positively correlated while they are negatively correlated to the market indicators of domestic companies (Figure 9).

\section{Conclusion}

The present study employs an instrument commonly used in financial studies, the event research technique, to analyse the impact of a seismic event that occurred in 1999 on Turkish tourist flows. The aim of the study is to highlight the potential application of an event analysis approach to tourism data that could be used to evaluate the effects of earthquakes on tourism. As defined by Çiftci \& Yetgin (2016), the crisis is a disruption that undermines basic assumptions about the system they are working on the participants. All the crises disrupt the order of business and cause a panic environment. In case of a crisis, it is necessary to take decisions promptly in order to return a business to its routine operations. The necessity to take prompt decisions may, however, cause to take wrong decisions. Therefore, the unforeseen crises cause psychological pressure on the governments, decrease productivity and are perceived as disasters (Çiftci, 2017).

The Maki Cointegration Test, which was used to checkwhether a structural break in the co-integration relationship between the number of tourist arrivals

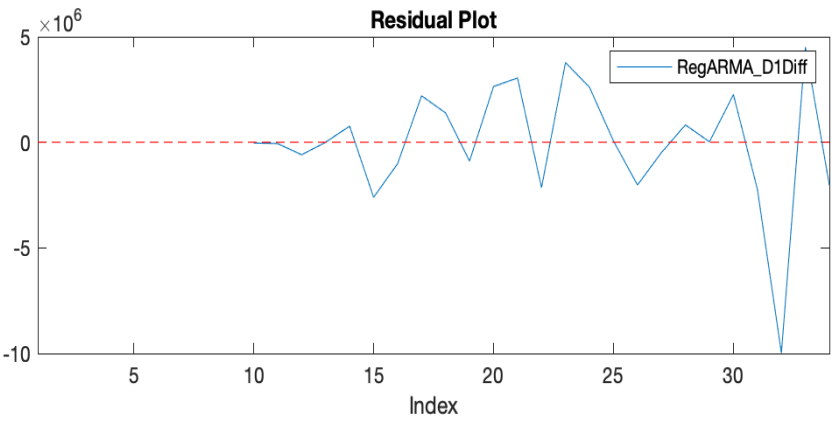

Figure 7. Regression ARMA Residual Plot Graph D1Diff Variable
Figure 8. Optimizable Ensemble Regression Model Between Number of Tourist Arrivals (D1) and GDP Growth (I1)

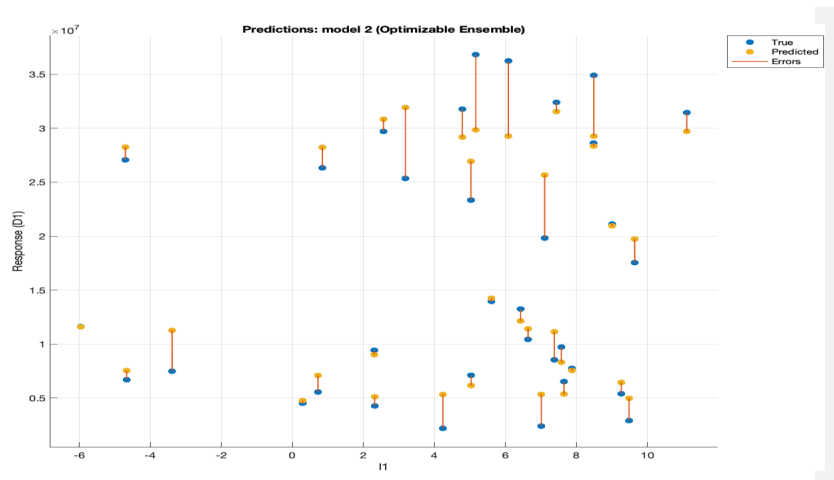

and other independent variables occurred as a result of the earthquake, verified that there occurred economic break-downs in 1994, 1996, 2010, 2012 and 2014. It points to the split encountered as a result of the 1999 Earthquake among those breakdowns. According to the results of the CUSUM and CUSUMSQ test, recursive residuals of the tourist number variable changed after the earthquake in 2000, which can help to identify structural change patterns when the break date is known. The results show that the number of tourists decreased by about $20 \%$ after the earthquake. The results of the CUSUM and CUSUMSQ estimation analysis based on the control variables reveal that the number of future tourists would have been approximately 8 percent higher than the number of incoming tourists if there had been no earthquakes. Multiple Linear Regression Model (MLR D1Diff) Estimation Results indicate that there was no regression relationship between the dependent variable (D1 tourist number) and the independent variables (I1-I5). The dependent variable (D1 number of tourists) is negatively correlated to the Listed Domestic Companies' market capitalization (I2) and positively correlated to all the other independent variables.

The advantages of the event study analysis would be that it makes it easy to measure the reliability of crises in contexts of irrational behaviour. The study of excess residues over time has made it possible to track the trend of the tourism crisis. The

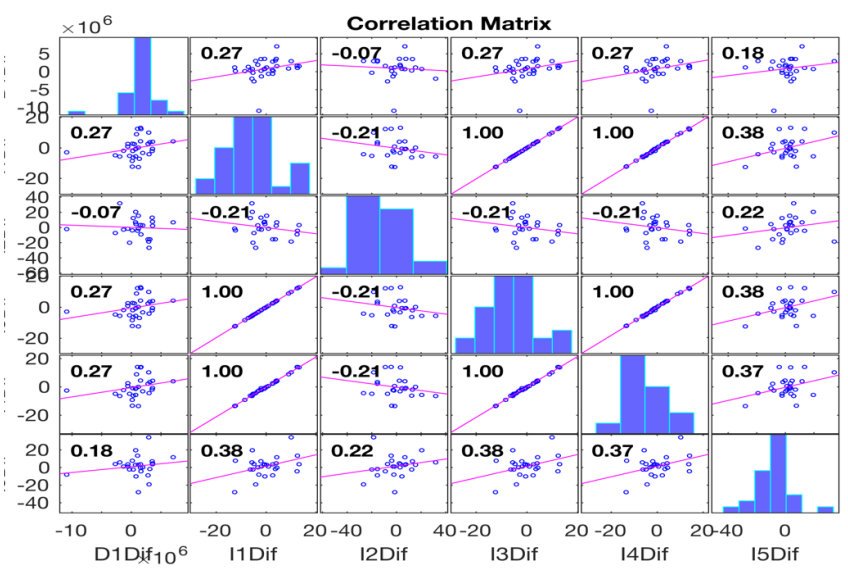

Figure 9. A matrix of plots showing the correlations between variables D1Diff, I1Diff, I2Diff, I3Diff, I4Diff, I5Diff 
effect on tourist arrivals seems to have been more conveniently absorbed back even though the initial reduction is readily apparent and valuable. Some of the statistical assemblages of the districts studied have created it difficult to quantify the temporal impact on tourist arrivals in various areas of the country. While many towns encountered the adverse effects of the earthquake, the strongest impact on international tourists had been noticed in Istanbul, which is nearest to the major earthquake hotbeds.

In addition, the tourism industry works in cooperation with many other sectors and offers an integrated service. Therefore, the tourism industry has a multiplier effect on the global and national economy. Thus, if the tourism industry suffers from any economic crisis, it means many other sectors from agriculture to textile will suffer extensively (Çiftçi, Küçükaltan, \& Menteş, 2017). For that reason, tourism officials and stakeholders must understand that conflicts and the fight for sustainable development can't be seen as linear processes since we live in non-linear environments where things are unpredictable. In order to gain a better understanding of the crisis, future research might follow the steps of the present study for other destinations and different contexts.

\section{Limitations}

Although research has some input, it also has some limitations. That the very first limiting factor is that there would be various crises that may impact a destination at one time. That being said, the approach helps determine only the structural breaks in an intracellular case and recognizes their dates; in such situations, it is hard to ascertain if either one of these crises is willing to take responsibility for the structural break in the market for international tourism. Second, provided the former identification of structural breaks, this should be acknowledged that the intentional monitoring of statistics for authentication purpose appears to be viable only under a certain time period.

\section{References}

Aktürk, İ., \& Albeni, M. (2002). Doğal Afetlerin Ekonomik Performans Üzerine Etkisi: 1999 Yılında Türkiye'de Meydana Gelen Depremler ve Etkileri. Süleyman Demirel Üniversitesi iktisadi ve Idari Bilimler Fakültesi Dergisi, 7(1), 1-18.

Anadolu Agency (2018). Accessed from: https://www. aa.com.tr/en/life/turkey-observes-19th-anniversaryof-marmara-earthquake/1234211, Date of Access: 01.08.2020.

Association of Turkish Travel Agencies (TURSAB). (2019). Accessed from https://www.tursab.org.tr/istatistikler/ turist-sayisi-ve-turizm-geliri, accessed date: 02.09.2019.

Bai, J., \& Perron, P. (2003). Computation and analysis of multiple structural change models. Journal of Applied Econometrics, 18(1), 1-22.

Bibbee, A., Gönenç, R., Jacobs, S., Konvitz, J., \& Price, R. (2000). Economic Effects of the 1999 Turkish Earthquakes,
OECD Economics Department Working Papers 247 (2), 9-17, https://dx.doi.org/10.1787/233456804045.

Biggs, D., Hall, C. M., \& Stoeckl, N. (2012). The resilience of formal and informal tourism enterprises to disasters: reef tourism in Phuket, Thailand. Journal of Sustainable Tourism, 20 (5), 645-665.

Binder, J. (1998). The event study methodology since 1969. Review of quantitative Finance and Accounting, 11(2), 111-137.

Bramwell, B. \& Lane, B. (2002) The Journal of Sustainable Tourism: The First Ten Years, Journal of Sustainable Tourism, 10 (1), 1-4, DOI: 10.1080/09669580208667149.

Brown, R., Durbin, J., \& Evans, J. (1975). Techniques for Testing the Constancy of Regression Relationships over Time. Journal of the Royal Statistical Society. Series B (Methodological), 37(2), 149-192, DOI:10.1111/j.2517-6161.1975.tb01532.x

Campbell, J. Y., Champbell, J. J., Campbell, J. W., Lo, A. W., Lo, A. W., \& MacKinlay, A. C. (1997). The econometrics of financial markets. Princeton University press, 149-180.

Chow, G. C. (1960). Tests of equality between sets of coefficients in two linear regressions. Econometrica: Journal of the Econometric Society, 28 (3), 591-605.

Cró, S., \& Martins, A. M. (2017). Structural breaks in international tourism demand: Are they caused by crises or disasters?. Tourism Management, 63 (1), 3-9.

Centre for Research on the Epidemiology of Disasters CRED (2015), The Human Cost of Natural Disasters, A Global Perspective, 07-41.

Çiftci, G. (2017). Politicial Crises' Implications on UNESCO World Heritage Sites. Karabük Üniversitesi Sosyal Bilimler Enstitüsü Dergisi, 7(1), 145-161.

Çiftci, G., Çakır, G., \& Çakır, A. (2016). Political crisis' and their implications on heritage sites: The case of Turkey. Journal of Tourism Theory and Research, 2(2), 89-97. DOI: $10.24288 / \mathrm{jttr} .279181$.

Çiftci, G., Küçükaltan, D., \& Menteş, S. A. (2017). Empirical Analysis Of Crisis Management Practices In Tourism Enterprises In Terms Of Organizational Learning. Business \& Management Studies: An International Journal, 5(1), 42.

Çiftci, G., \& Yetgin, D. (2016). Teröre Dayalı Krizler ve Sosyal Medya: Türkiye Örneği, 17. Ulusal Turizm Kongresi, 2023 Ekim 2016. Bodrum- Muğla/ Türkiye.

Demir, E., Simonyan, S., Chen, M.-H., \& Marco Lau, C. K. (2020). Asymmetric effects of geopolitical risks on Turkey's tourist arrivals. Journal of Hospitality and Tourism Management, 45 (1), 23-26. doi:10.1016/j. jhtm.2020.04.006

Dickey, D. A., \& Fuller, W. A. (1979). Distribution of the estimators for autoregressive time series with a unit root. Journal of the American statistical association, 74(366a), 427-431.

Dickey, C., \& Kohen, S. (1999). Tremor Terror. Newsweek, 134 (18), 94-94.

Ewing, B. T., Kruse, J. B., \& Özdemir, Ö. (2004). Disaster Loses in the Developing World: Evidence from the August 1999 Earthquake in Turkey, Discussion Paper, No. 2004/19, Turkish Economic Association, Ankara.

Faulkner, B. (2001). Towards and framework for tourism disaster management. Tourism Management 22 (2), 
135-147.

Fisher, F. (1970). Tests of Equality Between Sets of Coefficients in Two Linear Regressions: An Expository Note. Econometrica, 38 (2), 361-366. DOI:10.2307/1913018.

Goetzl, D., \& Healy, B. (2000). Turkey lures visitors with historical appeal. Advertising Age, 71 (26), 50-51.

Gregory, A. W., \& Hansen, B. E. (1996). Residual-based tests for cointegration in models with regime shifts. Journal of Econometrics, 70 (1), 99-126. DOI:10.1016/03044076(69)41685-7.

Hatemi-J, A. (2008). Tests for cointegration with two unknown regime shifts with an application to financial market integration. Empirical Economics, 35 (3), 497505. DOI:10.1007/s00181-007-0175-9.

Huang, J. H., \& Min, J. C. (2002). Earthquake devastation and recovery in tourism: the Taiwan case. Tourism Management, 23 (2), 145-154.

Hyndman, R. J. (2010). "The ARIMAX Model Muddle.", Accessed from https://robjhyndman.com/hyndsight/ arimax/ Accessed date: 12.08.2020.

Jorm, A. F., Scott, R., Cullen, J. S., \& MacKinnon, A. J. (1991). Performance of the Informant Questionnaire on Cognitive Decline in the Elderly (IQCODE) as a screening test for dementia. Psychological medicine, 21(3), 785790.

Kapetanios, G. (2005). Unit-root testing against the alternative hypothesis of up to $m$ structural breaks. Journal of Time Series Analysis, 26 (1), 123-133.

Kaya, A., Yetgin Akgün, D., \& Çiftci, G. (2020). The Relationship of Crisis on Professional Attitudes of Tour Guiding Students, Journal of Turkish Tourism Research, 4(3): 2907-2923.

Kontogeorgopoulos, N. (1999). Sustainable tourism or sustainable development? Financial crisis, ecotourism, and the'Amazing Thailand'campaign. Current Issues in Tourism, 2 (4), 316-332.

Liu, Y., Cheng, P., \& OuYang, Z. (2019). Disaster risk, risk management, and tourism competitiveness: A crossnation analysis. International Journal of Tourism Research, 21 (6), 855-867.

Kwiatkowski, D., Phillips, P. C., Schmidt, P., \& Shin, Y. (1992). Testing the null hypothesis of stationarity against the alternative of a unit root: How sure are we that economic time series have a unit root?. Journal of econometrics, 54 (1-3), 159-178.

MacKinnon, J. G. (1996). Numerical distribution functions for unit root and cointegration tests. Journal of applied econometrics, 11(6), 601-618.

Maki, D. (2012). Tests for cointegration allowing for an unknown number of breaks. Economic Modelling, 29 (5), 2011-2015. DOI:10.1016/j.econmod.2012.04.022

Mazzocchi, M., Montini, A. \& Zoboli, R. (1999). Vulnerabilita socio-economica, flussi turistici e rischi sismici. Quaderni Dynamis IDSE-CNR.

Mendoza, C. A., Brida, J. G., \& Garrido, N. (2012). The impact of earthquakes on Chile's international tourism demand. Journal of Policy Research in Tourism, Leisure and Events, 4 (1), 48-60.

Mistilis, N., \& Sheldon, P. (2006). Knowledge management for tourism crises and disasters. Tourism Review International, 10 (12), 39-46.
DOI:10.3727/154427206779307330

Mitchell, M. L. (1989). The impact of external parties on brand-name capital: The 1982 tylenol poisonings and subsequent cases. Economic inquiry, 27 (4), 601-618.

Akgiray, V., Barbarosoglu, G., \& Erdik, M. (2004). The 1999 Marmara Earthquakes in Turkey. Large-scale disasters: lessons learned. Organisation for Economic Cooperation and Development, OECD Publishing, 77-92.

Page, E. S. (1954), Continuous Inspection Schemes, Biometrika, 41 (1) 100-115.

Perron, P. (1989). The great crash, the oil price shock, and the unit root in time series regression. Econometrica, 57 (1), 1361-1401.

Perron, P., \& Vogelsang, T. J. (1992). Nonstationarity and level shifts with an application to purchasing power parity. Journal of business \& economic statistics, 10 (3), 301-320.

Petal, M., \& Turkmen, Z. (2002). ABCD Basic Disaster Awareness Handbook. Istanbul: Beyaz Gemi.

Ritchie, B. (2008). Tourism disaster planning and management: From response and recovery to reduction and readiness. Current issues in Tourism, 11 (4), 315348.

Sausmarez, N. (2007). Crisis Management, Tourism and Sustainability: The Role of Indicators, Journal of Sustainable Tourism, 15 (6), 700-714, DOI: 10.2167/ jost653.0.

Strong, N. (1992). Modelling abnormal returns: A review article. Journal of Business Finance \& Accounting, 19 (4), 533-553.

The World Bank (1999), Turkey Country Office, Marmara Earthquake Assessment, 39-41 https://www.gfdrr.org/ sites/default/files/publication/pda-1999-turkey.pdf, Accessed date: 12.08.2020.

Vere-Jones, D. (1995). Forecasting earthquakes and earthquake risk. International Journal of Forecasting, 11 (4), 503-538.

Wu, L., \& Hayashi, H. (2013). The impact of the great east Japan earthquake on inbound tourism demand in Japan. 地域安全学会論文集, 21 (2), 109-117.

Wu, L., \& Hayashi, H. (2014). The impact of disasters on Japan's inbound tourism demand. Journal of Disaster Research, 9(sp), 699-708.

Xu, Q., Chang, V., \& Hsu, C. H. (2020). Event study and principal component analysis based on sentiment analysis-a combined methodology to study the stock market with an empirical study. Information Systems Frontiers, 22 (5), 1021-1037.

Yetgin, D., Yılmaz A., \& Çiftci, G. (2018). Krizlerin Turist Rehberliği Öğrencilerinin Kariyer Planlamasındaki Etkisi, Journal of Tourism and Gastronomy Studies, 6 (3), 195214.

Zhao, L., Li, M., Chen, S., Chen, Y., Wang, Y., \& Zhang, Y. (2020, May). A Study on Event-Oriented Text Retrieval with Deep Neural Network. In 2020 5th IEEE International Conference on Big Data Analytics (ICBDA), 386-392. 


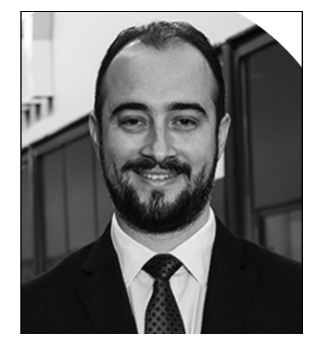

Sonat Bayram is an experienced Assistant Professor (Certificated Public Accountant, CPA) with a demonstrated history of working in the financial sector and Universities. Skilled in Budgeting, Valuation, Corporate Finance, Financial Quantitative Techniques, Accounting, Analytical Skills, Government, Law (LL.B.), Public Speaking, and English.

ORCID: 0000-0001-9885-8707

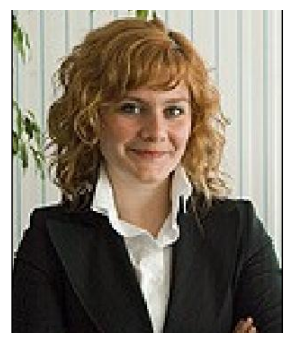

Gülsel Çiftçi is an Assistant Professor at Trakya University in Edirne in Turkey. After completing her undergraduate and graduate educations at Gazi University, she received her PhD from Namik Kemal University with a dissertation titled "An Empirical Analysis of Crisis Management Practices in the Tourism Establishments In Terms Of Organizational Learning and Business Performance". Her interest areas are crisis management in the hospitality and tourism industry, tour guiding and cross-border shopping tourism. She is also a licenced professional tourist guide. Her area of expertise as a tourist guide is Gallipoli Peninsula Historical National Park in Çanakkale.

ORCID: 0000-0001-8382-3309 